\title{
PENGARUH MEDIA SOSIAL TERHADAP PENYIMPANGAN PERILAKU PADA SISWA
}

\author{
Rosyidah \\ Guru MTS Muhammadiyah I Mungkid Kabupaten Magelang \\ email: homekomputer81@gmail.com
}

\section{Abstract}

Today the use of facebook / twitter has become a daily routine. The number of students using the facebook / twitter, making them aside obligations, even making it a hobby without knowing the time. Seeing the development of facebook / twitter that many favored particularly adolescents, as well as the resulting negative impact, encourage researchers to conduct research on the impact of media facebook / twitte against deviant behavior in students. The purpose of this study was to determine the effect of media facebook / twitter to deviations of student behavior MTs Muhammadiyah 1 Mungkid. This research is a quantitative research with the entire student population of MTs Muhammadiyah Mungkid. The sample used a number of 62 students with proportional random sampling. Data collection method used is the questionnaire method and documentation. Data analysis technique using linear regression statistical test. The results showed that there was a significant relationship between media use facebook / twitter to deviations of student behavior MTs Muhammadiyah 1 Mungkid. It is based on linear regression analysis obtained regression coefficient of 1.098 with significant value $0.000>0.05$. So when the media use facebook / twitter increases, the deviant behavior of students will also be increased.
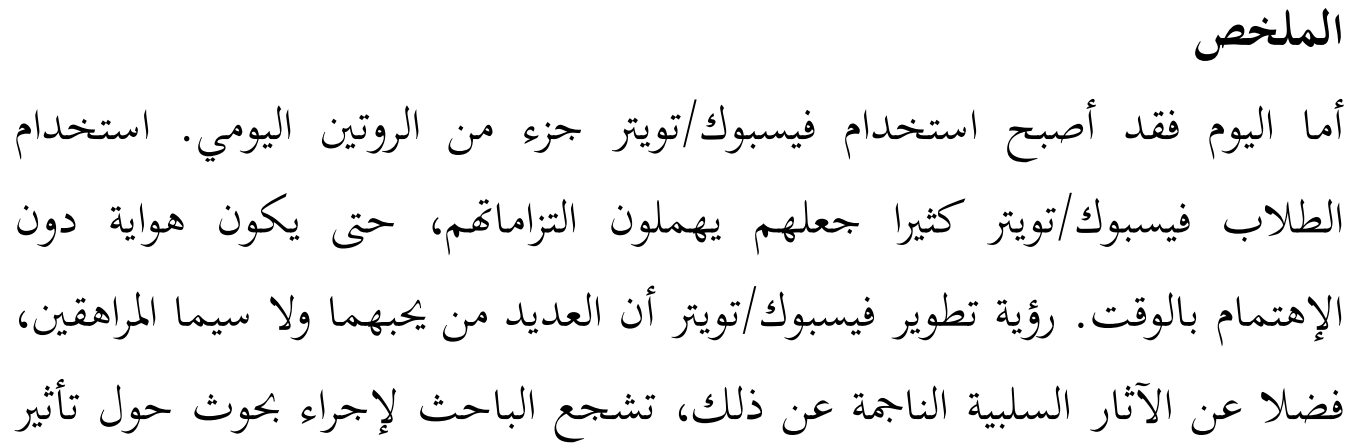
وسائل الإعلام فيسبوك/تويتر إلى السلوك المنحرف لدى الطلاب. وكان الغرض من

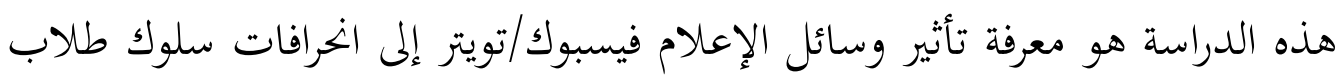

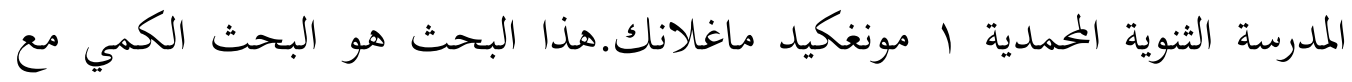
عدد طلاب المدرسة الثنوية المحمدية ا مونغكيد بأكملهم. استخدمت العينة عدد مأسية

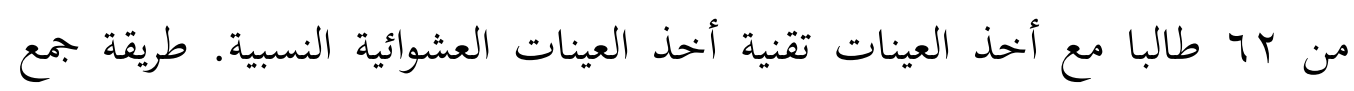
البيانات المتبعة هي أسلوب الاستبيان والوثائق. تقنية تحليل البيانات باستخدام

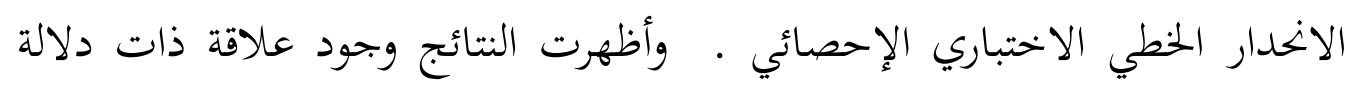

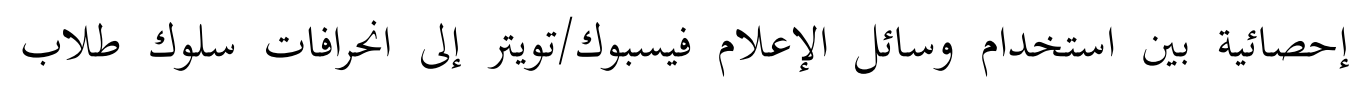

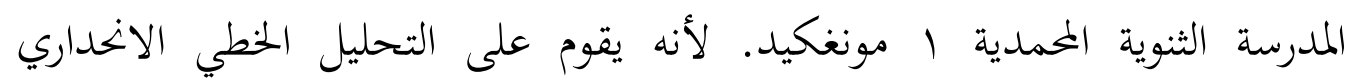

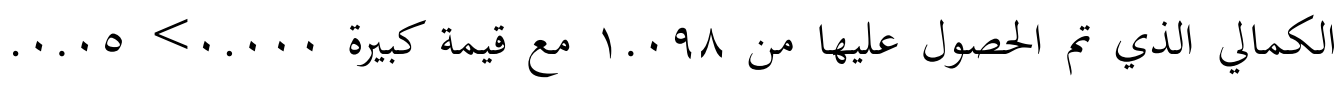
وذلك عندما يزيد استخدام وسائل الإعلام فيسبوك/تويتر كما ستتم زيادة السلوك فئه

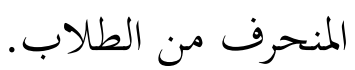

Keywords: Media Facebook/Twitter, Perilaku Menyimpang

\section{A. Pendahuluan}

Komputer dan internet merupakan salah satu bentuk pesatnya perkembangan teknologi informasi. Banyak memudahan dan manfaat yang dapat diambil dari kemajuan teknologi komputer dan internet. Hampir semua masyarakat sebagai pengguna teknologi informasi dan komunikasi, membuktikan bahwa kehidupan tidak dapat lepas dari peran teknologi informasi. Di era internet ini, jenis media sosial online sangat beragam. Salah satunya yang paling populer adalah Facebook/twitter.

Facebook/twitteratau situsjejaring sosialinilahirdiCambridge, Massachusetts 14 Februari 2004 oleh Mahasiswa Harvard bernama Mark Zuckerberg. Menurut data di Alexa, Facebook/twitter adalah mesin jejaring sosial nomor satu. Dalam 
urutan keseluruhan situs di dunia, Facebook/twitter menempati rangking ke-5 setelah Yahoo, Google, YouTube, dan Windows Live. Kepopuleran Facebook/ twitter di Indonesia, mulai tahun 2008 dengan jumlah spektakuler pengguna Facebook/twitter yakni sebesar 618\%. ${ }^{1}$

Facebook/twitter merupakan salah satu situs pertemanan atau jejaring sosial yang belakangan sangat berkembang pesat dibanding situs pertemanan lainnya. Berdasarkan informasi dari checkfacebook/twitter.com, pengguna facebook/twitter mencapai 300 juta orang dan pertambahannya akan terus meningkat di setiap minggunya. Indonesia tergolong negara ke tujuh terbesar pengguna facebook/twitter, hampir mencapai 12 juta orang dan jumlah ini terus mengalami pertumbuhan rata-rata $6 \%$ per minggu. ${ }^{2}$

Facebook/twitter sendiri adalah website jaringan sosial dimana para pengguna dapat bergabung dalam komunitas seperti kota, kerja, sekolah, dan daerah untuk melakukan koneksi dan berinteraksi dengan orang lain. Orang juga dapat menambahkan teman-teman mereka, mengirim pesan, dan memperbarui profil pribadi agar orang lain dapat melihat tentang dirinya.

Pengguna facebook/twitter seringkali disebut Facebooker/twitterer. Mayoritas facebooker/twitterer menggunakan facebook/twitter untuk terkoneksi dengan keluarga, relasi, dan teman-teman. Facebook/twitter menyebabkan jaringan relasi semakin luas karena penemuan-penemuan baru relasi senantiasa tercipta. Tidak hanya itu, facebook/twitter mampu membuka gerbang komunikasi sehingga kontak dapat terus dilakukan. Selain itu, facebook/twitter memiliki fasilitas newsfeed yang memudahkan facebook/twitter mengakses informasi dengan terorganisasi dan pengingatnya seperti pemberitahuan aktivitas teman facebook/ twitter lain serta pesan-pesan layaknya e-mail cukup digemari banyak facebook/ twitter.

Saat ini penggunaan facebook/twitter di Indonesia sudah menjadi rutinitas sehari-hari, mulai dari pelajar, mahasiswa, guru, dosen, pengusaha, pengacara, politisi, artis, tokoh-tokoh dunia dan lain-lain, dan dari berbagai kelas dan golongan karena masalah penggunaan internet sudah bukan barang yang mahal. Hal ini disebabkan hanya dengan beberapa ribu rupiah saja sudah bisa menjelajah ke

1 Duminikus Juju \& Feri Sulianta, Hitam Putih Facebook (Jakarta: PT. Elex Media Komputindo, 2010), hal. 6.

${ }^{2}$ Ibid., hal 7 
dunia maya sehingga penggunaan facebook/twitter merupakan hal yang biasa seperti penggunaan internet pada umumnya.

Sekarang ini Indonesia telah menjadi 'the Republic of the facebook/twitter'. Ungkapan ini terinspirasi oleh perkembangan penggunaan facebook/twitter oleh masyarakat Indonesia yang mencapai pertumbuhan $64,5 \%$ pada tahun 2008. Prestasi ini menjadikan Indonesia sebagai 'the fastest growing country on facebook/twitter in Southeast Asia'. Bahkan, angka ini mengalahkan pertumbuhan pengguna facebook/twitter di China dan India yang merupakan peringkat teratas populasi penduduk di dunia. ${ }^{3}$

Di balik semua sisi positifnya ternyata tidak dapat dipungkiri, facebook/ twitter menyimpan pula sisi negatifnya.Terutama kasus-kasus kejahatan melalui media facebook/twitter yang menimpa para remaja sebagai korbannya. Maraknya, pelecehan seksual, praktek prostitusi, tindakan asusila, pertengkaran, penghinaan, pencemaran nama baik, dan cybercrime lainnya yang turut melibatkan remaja banyak ditemui melalui facebook/twitter. Dampak negatif facebook/twitter dapat pula dibuktikan dengan penelitian baru oleh kandidat program doctoral dari Ohio State University, Aryn Karpinski dan rekannya Adam Durberstein dari Ohio Dominican University, menunjukkan nilai rata-rata IPK mahasiswa yang menjadi anggota Facebook turun secara signifikan dibandingkan mereka yang tidak bergabung dengan Facebook. Perbandingannya, nilai IPK bagi mahasiswa anggota Facebook mencapai 3,03,5, sedangkan mahasiswa yang bukan anggota Facebook, mampu mencapai 3,5-4,0. Hasil studi Ohio State University juga menyebutkan bahwa "semakin sering Anda menggunakan Facebook, semakin sedikit waktu Anda belajar dan semakin buruklah nilai-nilai mata pelajaran Anda."4

Banyaknya pelajar yang terlena dengan fasilitas website hiburan dari teknologi informasi seperti facebook, chatting, twitter dan sebagainya, membuat mereka menyampingkan kewajibannya, bahkan mereka menjadikan hal tersebut sebagai hobi yang dilakukan tanpa mengenal waktu. Konsekuensinya, para pelajar akan menjadi malas dan semakin membutakan kesadaran mereka

3 Sahana, Facebook Indonesia Outpaces Southeast Asian Counterparts in 2008, dikutip dari http://www.insidefacebook.com/2008/12/31/facebook-indonesia-outpacessoutheast-asiancounterparts-in-2008/ diakses 10 November 2012.

4 Ratih Dwi Kusumaningtyas, Peran Media Sosial Online (Facebook) sebagai Saluran Self Disclosureremaja Putri di Surabaya, (Surabaya: Skripsi Fisipol UPN Veteran, 2010), hal. 10. 
tentang pentingnya sadar teknologi. Inilah sebenarnya sisi paling buruk yang tidak dapat dihindarkan dan disembunyikan dari kemajuan teknologi informasi dewasa ini, karena dampak negaitf tersebut dapat mengubah paradigma pelajar dalam menghadapi era teknologi informasi dan komunikasi.

Pola komunikasi Internet melalui situs pertemanan facebook/twitter ini, pada tahap tertentu bisa menimbulkan adiksi yang mungkin berpengaruh terhadap kehidupan nyata. Beberapa ciri-ciri orang yang teradiksi terhadap internet, yaitu penggunaan yang berlebihan, kegelisahan ketika tidak mengakses internet dalam interval waktu tertentu, peningkatan toleransi terhadap adiksi internet itu sendiri, dan dampak negatif (termasuk isolasi sosial). ${ }^{5}$

Dalam dunia pekerjaan isu ini mendapat perhatian khusus. Beberapa perusahaan menutup akses situs jejaring sosial di area perkantorannya. Hal ini dilakukan karena banyak pegawai ketika jam kerja membuka facebook/twitte dan membuat kinerja mereka menurun. Dalam kerangka dunia pendidikan, keberadaan facebook/twitte juga mendapat sorotan. Sebuah survey yang dilakukanoleh Ohio University, menyebutkan bahwa mahasiswa yang sering menggunakan facebook/twitter ternyata menjadi malas dan bodoh. ${ }^{6}$

Kasus-kasus berdampak negatif pada facebook/twitter cenderung dialami para remaja. Hal ini dapat dikarenakan ketidakmatangan seorang remaja dalam mengenali identitas diri maupun lingkungannya. Mengingat usia remaja merupakan masa pencarian dan pengukuhan jati diri sebelum menginjak usia dewasa. Remaja bahasa aslinya adalah adolescence, berasal dari bahasa latin yang artinya "tumbuh untuk mencapai keuntungan". Perkembangan lebih lanjut istilah adolescence sesungguhn ya memiliki arti yang luas, yakni mencakup kematangan mental, emosional, sosial, dan fisik.secara psikologis, remaja adalah suatu usia yang menempatkan individu menjadi terintegrasi ke dalam masyarakat dewasa, anak tidak merasa bahwa dirinya berada di bawah tingkat orang yang lebih tua melainkan merasa sama, atau paling tidak sejajar.

Remaja yang masih berjiwa labil dan emosional sering salah menafsirkan apa yang mereka dapatkan baik dari media massa maupun darisitus pertemanan.

5 Christiany Juditha, “Hubungan Penggunan Situs Hubungan Jejaring Sosial Facebook terhadap Perilaku Remaja di Kota Makasar", dalam Jurnal Penelitian IPTEK-KOM, Volume 13, No. I, (Juni 2011), hal. 7.

6 Ibid., 
Keadaan yang seperti demikian menjadikan remaja sering terpancing rasa keingintahuannya untuk mencoba apa yang ditawarkan kepada mereka melalui media-media tersebut yang kemudian memunculkan perubahan perilaku baik itu yang positif maupun negatif pada diri remaja. ${ }^{7}$

Melihat perkembangan facebook/twitter yang semakin familiar dan banyak disenangi oleh pengguna internet di Indonesia khususnya remaja, sekaligus dampak-dampak negatif yang ditimbulkannya serta berindikasi memiliki peran yang kuat dalam menfasilitasi penggunanya untuk melakukan interaksi sosial melalui komunikasi, mendorong peneliti untuk melakukan penelitian "Pengaruh Media Facebook/twitter terhadap Penyimpangan Perilaku Siswa MTs Muhammadiyah 1 Mungkid Kabupaten Magelang”.

Berdasarkan latar belakang diatas fokus dalam penelitian ini adalah tentang pengaruh media facebook/twitter terhadap penyimpangan perilaku siswa MTs Muhammadiyah 1 Mungkid Kabupaten Magelang. Tujuan diadakan penelitian ini untuk mengetahui pengaruh media facebook/twitter terhadap penyimpangan perilaku siswa MTs Muhammadiyah 1 Mungkid Kabupaten Magelang. Sedangkan manfaat yang akan diperoleh dari penelitian ini adalah dapat memberi sumbangan penelitian yang berguna bagi peningkatan keilmuan khususnya dalam perilaku siswa dan dapat menjadi sumber yang akurat untuk memberikan informasi dan rekomendasi bagi guru mengenai pengelolaan perilaku siswa.

\section{B. Landasan Teori}

\section{Penyimpangan Perilaku}

Perilaku disebut juga akhlak secara etimologis berasal dari kata (lughatan) akhlaq (Bahasa Arab) adalah bentuk jamak dari khuluq, berakar dari kata khalaqa yang berarti menciptakan. Seakar dengan kata Khaliq (Pencipta), makhluq (yang diciptakan) dan khalq (penciptaan). Dan pengertian etimologis seperti ini, akhlaq bukan saja merupakan tata aturan atau norma perilaku yang mengatur hubungan antar sesama manusia, tetapi juga norma yang mengatur hubungan antara manusia dengan Tuhan dan bahkan dengan alam semesta sekalipun. Secara terminologis perilaku atau akhlak menurut Imam Ghozali adalah sifat yang tertanam dalam jiwa yang menimbulkan perbuatan-perbuatan dengan 
gampang dan mudah, tanpa memerlukan pemikiran dan pertimbangan. Ibrahim Anis mendefinisikan perilaku adalah sifat yang tertanam dalam jiwa, yang dengannya lahirlah macam-macam perbuatan, baik atau buruk, tanpa membutuhkan pemikiran dan pertimbangan ${ }^{8}$.

Berdasarkan definisi di atas, dapat disimpulkan bahwa perilaku atau akhlak adalah sifat yang tertanam dalam jiwa manusia, sehingga dia akan muncul secara spontan bilamana diperlukan, tanpa memerlukan pemikiran atau pertimbangan lebih dahulu, serta tidak memerlukan dorongan dari luar.

Dalam Kamus Besar Bahasa Indonesia perilaku menyimpang diartikan sebagai tingkah laku, perbuatan, atau tanggapan seseorang terhadap lingkungan yang bertentangan dengan norma-norma dan hukum dalam masyarakat. ${ }^{9}$ Perilaku menyimpang menurut Bruce J. Cohen adalah setiap perilaku yang tidak berhasil menyesuaikan diri dengan kehendak-kehendak masyarakat dalam masyarakat. ${ }^{10}$

James Vender Zender mengartikan perilaku menyimpang adalah perilaku yang dianggap sebagai hal tercela dan di luar batas-batas toleransi oleh sejumlah besar orang. Sedangkan Robert M.Z. Lawang mengartikan perilaku menyimpang sebagai semua tindakan yang menyimpang dari norma-norma yang berlaku dalam suatu sistem sosial dan menimbulkan usaha dari mereka yang berwenang dalam sistem itu untuk memperbaiki perilaku tersebut. Perilaku menyimpang adalah setiap perilaku yang tidak sesuai dengan normanorma dalam masyarakat. Sedangkan pelaku yang melakukan penyimpangan itu disebut devian (deviant). Adapun perilaku yang sesuai dengan norma dan nilai yang berlaku dalam masyarakat disebut konformitas. ${ }^{11}$

Penyimpangan terhadap norma-norma atau nilai-nilai masyarakat disebut deviasi (deviation), sedangkan pelaku atau individu yang melakukan penyimpangan disebut devian (deviant). Kebalikan dari perilaku menyimpang adalah perilaku yang tidak menyimpang yang sering disebut dengan

8 Yunahar Ilyas, Kuliah Akhlaq, (Yogyakarta: LPPI Universitas Muhammadiyah Yogyakarta, 2006), hal. 1.

9 Kamus Besar Bahasa Indonesia (Jakarta: Balai Pustaka, 2008), hal. 236.

10 Wikipedia, Perilaku Menyimpang, dikutip dari http://id.wikipedia.org/wiki/Teori_konflik diakses_3 November 2012.

11 Hefri Asra Omika, Perilaku Menyimpang, dikutip dari http://infosos.wordpress.com/ kelas-x/perilaku-menyimpang/diakses 15 Maret 2013. 
konformitas. Konformitas adalah bentuk interaksi sosial yang di dalamnya seseorang berperilaku sesuai harapan kelompok.

Perilaku menyimpang biasanya disamakan atau identik dengan kenakalan remaja yaitu suatu tindak perbuatan yang bertentangan dengan hukum, agama, norma-norma masyarakat, sehingga berakibat merugikan orang lain, mengganggu ketentraman umum dan juga merusak dirinya sendiri. Mengenai bentuk atau jenis perilaku menyimpang pada remaja tetap ada di sepanjang zaman, hanya frekuensi dan akibat-akibatnya pada zaman sekarang dengan teknologi modern menjadi semakin meningkat sesuai perkembangan teknologi tersebut.

Di masyarakat kita mengenal bentuk-bentuk penyimpangan yang terdiri atas penyimpangan individual (individual deviation), penyimpangan kelompok (group deviation), dan penyimpangan gabungan dari keduanya (mixture of both deviation). Terkadang ada pula yang menambahkan dengan penyimpangan primer (primary deviation) dan penyimpangan sekunder (secondary deviation). Sedangkan penyimpangan perilaku pada remaja khususnya pada anak sekolah dapat dilihat pada perilaku sebagai berikut:

a. Membohong: memutar - balikkan kenyataan denagn tujuan menipu orang atau menutupi kesalahan.

b. Membolos: pergi meninggalkan sekolah tanpa sepengetahuan pihak sekolah.

c. Menggunakan kata-kata kotor dan kurang sopan dalam berkomunikasi.

d. Kabur: meninggalkan rumah tanpa izin orang tua atau menentang keinginan orang tua.

e. Sikap individualisme yang tinggi, enggan bersosialisasi dengan teman dan tidak penduli dengan lingkungan sekitar.

f. Keluyuran: pergi sendiri maupun berkelompok tanpa tujuan, dan mudah menimbulkan perbuatan iseng yang negatif.

g. Bersenjata tajam: memiliki dan membawa benda yang membahayakan orang lain, sehingga mudah terangsang untuk mempergunakannya.

h. Pergaulan buruk: bergaul dengan teman yang memberi pengaruh buruk, sehingga mudah terjerat dalam perkara yang benar-benar kriminal.

i. Membaca pornografi: membaca buku-buku cabul, pornografi dan 
kebiasaan menggunakan bahasa yang tidak sopan, tidak senonoh, seolah-olah menggambarkan kurangnya perhatian dan pendidikan dari orang dewasa.

j. Mengkompas: secara berkelompok meminta uang pada orang lain dengan paksa, makan di rumah makan tanpa membayar.

k. Merusak diri dengan cara mentato tubuhnya, minum-minuman keras, menghisap ganja, pecandu narkoba, sehingga merusak dirinya maupun orang lain. ${ }^{12}$

Penyimpangan perilaku pada dasarnya dipengaruhi oleh faktor internal dan faktor eksternal. Faktor internal meliputi konflik batiniah, pemasukan intrapsikis yang keliru, menggunakan reaksi frustasi negatif sedangkan faktor eksternal meliputi faktor keluarga, faktor sekolah dan faktor lingkungan. ${ }^{13}$

\section{Media Sosial, Facebook dan Twitter}

Facebook/twitter merupakan merupakan jejaring sosial, yakni suatu struktur sosial yang terbentuk dari simpul-simpul (individu atau organisasi) yang dihubungkana tau dipersatukan oleh sebuh situs. ${ }^{14}$ Menurut Asdani Kindarto, jejaring sosial adalah suatu struktur sosial yang dibentuk dari simpul-simpul (yang umumnya adalah individu atau organisasi) yang diikat dengan satu tipe relasi spesifik atau lebih, seperti nilai, visi, ide, teman, keturunan dan sebagainya ${ }^{15}$

Facebook dalam Wikipedia adalah sebuah layanan jejaring sosial dan situs web yang diluncurkan pada bulan Februari 2004 yang dimiliki dan dioperasikan olehFacebook, Inc. Facebook didirikan oleh MarkZuckerberg bersama temannya dan sesama mahasiswa ilmu komputer Eduardo Saverin, Dustin Moskovitz dan Chris Hughes. Keanggotaan situs web ini awalnya terbatas untuk mahasiswa Harvard saja, kemudian diperluas ke perguruan lain di Boston, Ivy League, dan Universitas Stanford. Situs ini secara perlahan membuka diri kepada maha-

12 Sarlito W. Sarwono, Psikologi Siswa (Jakarta: Rajawali Press, 2012), hal. 256.

13 Hadimunah, Penyebab Perilaku Menyimpang, dikutip dari http://id.shvoong.com/socialsciences/education/ diakses 3 November 2012

14 Madcom. Student Book Series: Mencari Teman lewat Facebook dan Friendster (Yogyakarta: Andi Offset, 2012), hal. 2

15 Asdani Kindarto. Efektif Blogging dengan Aplikasi Facebook (Jakarta: PT. Media Elex Komputindo, 2010), hal. 2 
siswa di universitas lain sebelum dibuka untuk siswa sekolah menengah atas, dan akhirnya untuk setiap orang yang berusia minimal 13 tahun. Meski begitu, menurut survei Consumer Reports bulan Mei 2011, ada 7,5 juta anak di bawah usia 13 tahun yang memiliki akun Facebook dan 5 juta lainnya di bawah 10 tahun, sehingga melanggar persyaratan layanan situs ini. Studi Compete.com bulan Januari 2009 menempatkan Facebook sebagai layanan jejaring sosial yang paling banyak digunakan menurut jumlah pengguna aktif bulanan di seluruh dunia.

Twitter dalam Wikipedia adalah sebuah situs web yang dimiliki dan dioperasikan oleh Twitter Inc., yang menawarkan jejaring sosial berupa mikroblog sehingga memungkinkan penggunanya untuk mengirim dan membaca pesan yang disebut kicauan (tweets). Kicauan adalah teks tulisan hingga 140 karakter yang ditampilkan pada halaman profil pengguna. Kicauan bisa dilihat secara luar, namun pengirim dapat membatasi pengiriman pesan ke daftar temanteman mereka saja. Pengguna dapat melihat kicauan penulis lain yang dikenal dengan sebutan pengikut ("follower"). ${ }^{16}$

Facebook/twitter merupakan jejaring sosial yang dapat memberikan berbagai kemudahan. Namun demikian ada sisi baik dan sisi buruk dari media tersebut. Dapak positif facebook/twitter diantaranya adalah memperluas pergaulan, sebagai media promosi bisnis dan media interaktif. ${ }^{17}$

Sejumlah studi mengatakan, FB membawa pengaruh baik pada orang usia lanjut, 50 tahun ke atas. Melalui FB yang mudah dioperasikan itu, para orang tua membuka kembali komunikasinya dengan banyak teman lamanya dan itu membawa pengaruh baik bagi perkembangan sosialnya.Semenjak situs jejaring sosial (facebook dan twitter) menyedot perhatian publik.

Dampak negatif dari situs jejaring sosial seperti facebook/twitter menurut siska adalah: ${ }^{18}$

a. Kecanduan situs jejaring sosial seperti Facebook atau MySpace juga bisa membahayakan kesehatan karena memicu orang untuk mengisolasikan diri. Meningkatnya pengisolasian diri dapat mengubah cara kerja gen, membingungkan respons kekebalan, level hormon, fungsi urat nadi,

16 Ibid.

17 Siska, Pengaruh Situs Jejaring Sosial Facebook, dikutip dari http://sisqute5.blogspot. com/2009. diakses 3 November 2012.

18 Ibid. 
dan merusak performa mental.

b. Seseorang yang menghabiskan waktunya di depan komputer akan jarangberolahraga sehingga kecanduanaktivitasini dapatmenimbulkan kondisi fisik yang lemah, bahkan obesitas.

c. Kerusakan fisik juga sangat mungkin terjadi. Bila menggunakan mouse atau memencet keypad ponsel selama berjam-jam setiap hari, seseorang dapat mengalami cedera tekanan yang berulang-ulang. Penyakit punggung juga merupakan hal yang umum terjadi, pada orang-orang yang menghabiskan banyak waktu duduk di depan meja komputer.

d. Media elektronik, seperti Komputer, laptop, atau handphone (ponsel) juga menghancurkan secara perlahan-lahan kemampuan anak-anak dan kalangan dewasa muda untuk mempelajari kemampuan sosial dan membaca bahasa tubuh. Maksudnya adalah seseorang akan mengalami pengurangan interaksi dengan sesama mereka dalam jumlah menit per hari-nya menyebabkan jumlah orang yang tidak dapat diajak berdiskusi mengenai masalah penting, menjadi semakin meningkat setiap harinya

e. Perilaku berkurangnya aktifitas berinteraksi langsung secara face to face terhadap orang lain juga dapat meningkatkan risiko kesehatan yang serius, seperti kanker, struk, penyakit jantung, dan dementia (kepikunan).

f. Sebuah penelitian terbaru dari Aryn Karpinski, peneliti dari Ohio State University, menunjukkan bahwa para mahasiswa pengguna FB ternyata mempunyai nilai yang lebih rendah daripada para mahasiswa non pengguna FB. Dari 219 mahasiswa yang diriset oleh Karpinski, 148 mahasiswa pengguna FB ternyata memiliki nilai yang lebih rendah daripada mahasiswa non pengguna. Menurut Karpinski, memang tidak ada korelasi langsung FB akan menyebabkan nilai para mahasiswa atau pelajar menjadi menurun. Namun diduga FB telah menyebabkan waktu belajar para siswa tersita oleh keasyikan berselancar di situs jaring sosial yang tengah populer ini. Para pengguna FB mengakui waktu belajar mereka memang telah tersita. Rata-rata para siswa pengguna FB kehilangan waktu antara 1 - 5 jam sampai 11 - 15 jam waktu belajarnya per minggu untuk bermain FB. 
Sebagian besar menghabiskan waktu berjam-jam untuk mengunjungi situs tersebut. dalam Ayupurwaning juga menjelaskan Facebook/ twitter juga membuat setiap orang seperti kaum siswa sekarang dan masyarakat cenderung bersifat individual. Oleh karena itu diperlukan cara untuk mengatasi kecanduan jaringan sosial ini seperti dengan membatasi waktu penggunaan internet, terutama situs jaringan sosial. Kita juga perlu belajar menggunakan jaringan internet secara bijak sehingga kita tidak menjadi orang yang candu akan jejaring sosial. Menurut penulis bagi pengguna situs jejaring sosial ini tidak harus berhenti total untuk tidak menikmati situs tersebut, namun lebih bijak kalau secara perlahan untuk menguranginya yaitu dengan mengurangi jam untuk bermain Facebook.

\section{Metode Penelitian}

Jenis penelitian ini adalah penelitian kuantitatif dengan populasi seluruh siswa MTs Muhammadiyah 1 mungkid Magelang sebanyak 100 siswa. Teknik pengambilan sampel menggunakan propotional random sampling yaitu sampel diambil dengan maksud dan tujuan tertentu karena peneliti menganggap bahwa sampel tersebut memiliki informasi yang diperlukan. Berdasarkan pengamatan yang dilakukan, diketahui bahwa hampir semua siswa memiliki HP dan hanya 2 siswa yang tidak memiliki HP. Namun demikian semua siswa memiliki akun FB, dan bagi siswa yang tidak memiliki HP ataupun HP yang tidak dapat untuk mengakses internet, maka FB dilakukan di warnet. Sampel yang digunakan adalah sebanyak 62 siswa dengan rincian siswa kelas VII 32 siswa dan kelas VIII 30 siswa, sedangkan siswa kelas IX tidak diikutkan dalam penelitian karena persiapan mengikuti ujian.

Variabel yang digunakan dalam penelitian ini meliputi variabel independen dan variabel dependen. Variabel independen (x), Variabel independen dalam penelitian ini adalah penggunaan media facebook dan twitter, yaitu siswa yang memiliki akun FB yaitu sarana sosial yang membantu siswa untuk berkomunikasi secara lebih efisien dengan teman-teman, keluarga, serta orang lain. Penggunaan PB/twitter yang diteliti disini meliputi frekuensi, waktu, aktifitas siswa pada FB yang bisa mempengaruhi perilaku pengguna. Indikator yang digunakan untuk mengukur variabel ini adalah: Intensitas penggunaan 
facebook/twitter, waktu penggunaan facebook/twitter, dan pemanfaatan facebook/ twitter

Variabel dependen (y) dalam penelitian ini adalah penyimpangan perilaku siswa yaitu tanggapan atau reaksi individu yang terwujud dari gerakan/tindakan (sikap), tidak saja badan tapi juga ucapan yang negatif akibat yang ditimbulkan dari penggunaan FB. Indikator yang digunakan untuk mengukur variabel ini adalah: perkataan siswa, kecanduan facebook/twitter, dan individualisme.

Data yang dikumpulkan untuk penelitian ini berupa data primer. Data ini dikumpulkan secara langsung dari lapangan, yang diperoleh dengan cara melakukan pengamatan, survei serta wawancara atau memberi daftar pertanyaan. Pada penelitian ini data primer diperoleh langsung dari siswa MTs Muhammadiyah Kota Mungkid Kabupaten Magelang tentang penyimpangan perilaku akibat facebook/twitter.

Metode pengumpulan data yang digunakan adalah metode angket. Metode ini memuat sejumlah pertanyaan-pertanyaan yang diajukan secara tertulis kepada siswa untuk memperoleh data tentang penggunaan media facebook/ twitter serta penyimpangan perilaku siswa. Instrumen yang digunakan adalah angket tertutup dalam bentuk pilihan berganda, yaitu pertanyaan yang sudah tersedia jawabannya sehingga responden hanya memilih jawaban yang sesuai. Penilaian jawaban responden untuk pernyataan positif jawaban A bernilai 4, jawaban B bernilai 3, jawaban C bernilai 2 dan jawaban D bernilai 1. Sedangkan untuk pernyataan negatif jawaban A bernilai 1, jawaban B bernilai 2, jawaban C bernilai 3 dan jawaban D bernilai 4 .

Untuk memperoleh angket yang baik, maka dilakukan expert judgement oleh dosen pembimbing serta dilakukan uji validitas dan reliabilitasnya. Validitas adalah kebenaran dan keabsahan instrumen penelitian yang digunakan ${ }^{19}$. Uji validitas ini dengan menggunakan nilai korelasi faktor, dan digunakan teknik analisis korelasi product moment dengan bantuan komputer SPSS 15,0 for windows. Angket dinyatakan valid apabila memiliki nilai $r$ hitung positif $>r$ tabel. Nilai r tabel untuk n 30 dan a 5\% adalah sebesar 0,349.

Variabel media facebook/twitter dan variabel penyimpangan perilaku di-

19 Imam Gozali, Aplikasi Analisis Multivariate dengan Program SPSS, (Semarang: Badan Penerbit Universitas Diponegero, 2009), hal. 45 
ukur menggunakan 30 butir angket dengan masing-masing variabel sebanyak 15 butir angket. Uji validitas dilakukan pada siswa kelas VIII yaitu sebanyak 30 siswa.

Hasil perhitungan uji validitas variabel media facebook/twitter diketahui bahwa terdapat satu butir angket dinyatakan gugur karena nilai $r$ hitung $<\mathrm{r}$ tabel yaitu angket nomor tujuh. Sedangkan 14 butir angket lainnya dinyatakan valid karena nilai $r$ hitung $>r$ tabel. Hasil perhitungan uji validitas variabel penyimpangan perilaku diketahui bahwa terdapat dua butir angket dinyatakan gugur karena nilai $\mathrm{r}$ hitung < $\mathrm{r}$ tabel yaitu angket nomor 26 dan nomor 27. Sedangkan 13 butir angket lainnya dinyatakan valid karena nilai $r$ hitung $>r$ tabel. Hasil uji validitas selengkapnya terlampir.

Reliabilitas adalah tingkat keajekan instrumen saat digunakan kapan dan oleh siapa saja sehingga akan cenderung menghasilkan data yang sama atau hampir sama dengan sebelumnya. ${ }^{20}$ Reliabilitas instrumen penelitian ini diukur dengan menggunakan teknik cronbach's alpha. Teknik analisis menggunakan bantuan komputer program SPSS 15,0 for windows. Variabel dinyatakan reliabel apabila nilai cronbach's alpha $>0,6 .{ }^{21}$

Hasil uji reliabilitas diketahui bahwa nilai cronbach alpha untuk kedua variabel yaitu media facebook/twitter dan penyimpangan perilaku $>0,6$ sehingga variabel yang digunakan untuk penelitian ini dinyatakan variabel dan dapat digunakan untuk penelitian selanjutnya.

Analisis data dalam penelitian ini adalah menggunakan analisis regresi linear yaitu untuk mengetahui pengaruh penggunaan media elektronik (facebook dan twitter) terhadap penyimpangan perilaku siswa. Teknik analisis data menggunakan bantuan komputer program SPSS 15.0 for windows. Kriteria pengujian untuk diterima atau ditolaknya hipotesis adalah dengan menggunakan alpha 5\%, yaitu apabila nilai koefisien regresi memiliki tingkat probabilitas < 0.05 (alpha 5\%), maka hipotesis yang diajukan diterima. ${ }^{22}$ Berarti ada pengaruh penggunaan media elektronik (facebook dan twitter) terhadap penyimpangan perilaku siswa.

\footnotetext{
${ }^{20}$ Ibid, hal.46.

21 Ibid.

22 Ibid.
} 


\section{Temuan Penelitian}

Hasil analisis dari jawaban angket diketahui bahwa penggunaan media facebook/twitter oleh siswa MTs Muhammadiyah Mungkid Kabupaten Magelang dalam kategori sedang. Hasil analisis dari jawaban angket responden juga menunjukkan bahwa penyimpangan perilaku siswa MTs Muhammadiyah Mungkid Kabupaten Magelang dalam kategori sedang. Perilaku menyimpang yang dimaksud adalah meliputi perkataan-perkataan kotor dan tidak sopan, kecanduan terhadap facebook/twitter dan sikap individualisme pada siswa.

Hasil analisis regresi linear membuktikan bahwa media facebook/twitter berpengaruh signifikan terhadap penyimpangan perilaku siswa MTs Muhammadiyah Mungkid Kabupaten Magelang. Penggunaan media facebook/twitter menyebabkan siswa menggunakan kata-kata kotor dan tidak sopan meski dalam gurauan, kecanduan terhadap facebook/twitter dan sikap individualisme pada siswa. Penelitian ini mendukung penelitian yang dilakukan oleh Juditha yang menyimpulkan bahwa ada pengaruh penggunaan situs jejaring sosial (FB) terhadap perilaku rejama. Hasil penelitian ini juga sejalan dengan pendapat Jerald yang menyatakan pola komunikasi Internet melalui situs pertemanan facebook/twitter ini, pada tahap tertentu bisa menimbulkan adiksi yang mungkin berpengaruh terhadap kehidupan nyata. Beberapa ciri-ciri orang yang teradiksi terhadap internet, yaitu penggunaan yang berlebihan, kegelisahan ketika tidak mengakses internet dalam interval waktu tertentu, peningkatan toleransi terhadap adiksi internet itu sendiri, dan dampak negatif (termasuk isolasi sosial).

Facebook/twitter merupakan merupakan jejaring sosial, yakni suatu struktur sosial yang terbentuk dari simpul-simpul (individu atau organisasi) yang dihubungkan atau dipersatukan oleh sebuh situs. Facebook/twitter adalah website jaringan sosial dimana para pengguna dapat bergabung dalam komunitas seperti kota, kerja, sekolah, dan daerah untuk melakukan koneksi dan berinteraksi dengan orang lain. Orang juga dapat menambahkan teman-teman mereka, mengirim pesan, dan memperbarui profil pribadi agar orang lain dapat melihat tentang dirinya.

Facebook/twitter yang saat ini banyak dimanfaatkan oleh masyarakat khususnya siswa yang menganjak usia remaja dapat mempengaruhi perilaku keseharian siswa yang masih sangat labil. Perilaku menyimpang yang ditimbulkan dapat dilihat dari perkataan siswa yang kurang sopan, penggunaan kata-kata kotor 
dalam komunikasi sehari-hari. Kecanduan terhadap facebook/twitter membuat siswa cenderungan menggunakan facebook/twitter kapanpun dan dimanapun ketika ada kesempatan meskipun saat pelajaran berlangsung. Perilaku menyimpang lainnya akibat facebook/twitter adalah sikap individualisme siswa yang semakin tinggi. Siswa cenderungan menggunakan facebook/twitter untuk berkomunikasi dan jarang bertemu langsung dengan teman. Hal tersebut dapat berakibat menurunnya sikap sosial pada siswa dan cenderung tidak peduli dengan lingkungan sekitarnya.

Perilaku menyimpang siswa MTS Muhammadiyah 1 Kota Mungkid akibat penggunaan facebook/twitter dapat dilihat pada perkataan dan perbuatan siswa saat mereka memanfaatkan facebook/twitter maupun dalam kehidupan seharihari. Mereka cenderung memperburuk cara berkomunikasi dan merusak tata bahasa. Dalam percakapan sehari-hari, banyak siswa menggunakan katakata kotor yang tidak lazim digunakan meski hanya dalam bergurau. Mereka menggunakan kata-kata baru dan kurang sopan yang biasa mereka pergunakan ketiga menggunakan facebook/twitter.

Perilaku menyimpang siswa juga dapat dilihat dari frekuensi, durasi, dan intensitas siswa saat memanfaatkan facebook/twitter. Siswa senantiasa menggunakan facebook/twitter kapanpun dan dimanapun termasuk dalam waktu belajar di sekolah. Mereka belum dapat mengontrol diri untuk tidak membuka facebook/twitter saat pelajaran berlangsung. Jadi ketika guru tidak mengetahuinya, kebanyakan siswa memanfaatkan facebook/twitter di dalam kelas. Hal tersebut berdampak pada menurunnya konsentrasi belajar siswa sehingga daya tangkap belajar siswa juga akan berkurang. Penggunaan facebook/ twitter juga dipengaruhi dikarenakan lingkungan yang mendukung, dimana saat semua teman-teman di sekitar mereka memanfaatkan situs jejaring sosial maka mereka juga akan melakukan hal yang sama. Hal ini akan sangat berguna bagi siswa dalam mencari teman baru mempererat hubungan dengan teman yang sudah ada, juga percaya atau sebaliknya kepada orang yang baru dikenal melalui facebook/twitter, mendapatkan banyak informasi, pengetahuan dan pengalaan baru sekaligus terhibur dan menghibur orang lain melalui facebook/ twitter atau sebaliknya mendapatkan masalah/musuh akibat facebook/twitter.

Penggunaan facebook/twitter pada siswa MTs Muhammadiyah 1 Kota Mungkid membentuk sikap siswa yang dapat dilihat secara langsung yaitu 
sikap individualisme yang tinggi. Mereka lebih menyukai berkomunikasi lewat facebook/twitter daripada bertemu langsung atau bertatap muka pada temannya.

Kasus-kasus berdampak negatif pada facebook/twitter cenderung dialami para siswa yang berusia menganjak remaja seperti siswa MTs Muhammadiyah Mungkid Magelang. Hal ini dapat dikarenakan ketidakmatangan seorang siswa dalam mengenali identitas diri maupun lingkungannya. Mengingat usia siswa merupakan masa pencarian dan pengukuhan jati diri sebelum menginjak usia dewasa. Perkembangan lebih lanjut bagi siswa yang menganjak usia remaja sesungguhnya mencakup kematangan mental, emosional, sosial, dan fisik. Remaja yang masih berjiwa labil dan emosional sering salah menafsirkan apa yang mereka dapatkan baik dari media massa maupun dari situs pertemanan. Keadaan yang seperti demikian menjadikan remaja sering terpancing rasa keingintahuanny untu mencoba dan mengikuti apa yang ditawarkan kepada mereka melalui media-media facebook/twitter yang kemudian memunculkan perubahan perilaku baik itu yang positif maupun negatif pada diri remaja.

\section{E. Penutup}

Berdasarkan hasil penelitian dan pembahasan tentang pengaruh media facebook/twitter terhadap penyimpangan perilaku pada siswa MTs Muhammadiyah Mungkid Kabupaten Magelang, maka dapat disimpulkan bahwa ada pengaruh yang signifikan $(0.000<0.05)$ antara penggunaan media facebook/twitter terhadap penyimpangan perilaku siswa MTs Muhammadiyah 1 Mungkid yang meliputi perkataan siswa dapat dilihat dari perkataan siswa yang kurang sopan, penggunaan kata-kata kotor dalam komunikasi seharihari. Kecanduan siswa terhadap facebook/twitter membuat siswa cenderungan menggunakanfacebook/twitter kapanpun dan dimanapun ketika ada kesempatan meskipun saat pelajaran berlangsung. Sikap individualisme siswa terlihat dari penggunaan facebook/twitter untuk berkomunikasi dan jarang bertemu langsung dengan teman yang mengakibatkan menurunnya sikap sosial pada siswa dan cenderung tidak peduli dengan lingkungan sekitarnya. 


\section{DAFTAR PUSTAKA}

Abu Nizar, Imam Ahmad. 2009. Membentuk \& Meningkatkan Disiplin Anak Sejak Dini. Yogyakarta: Diva Press.

Arikunto, Suharsimi. 1992. Prosedur Penelitian Suatu Pendekatan Praktik. Bandung: Rineka Cipta.

Azwar, Saifudin. 2003. Sikap Manusia: Teori dan Pengukurannya. Yogyakarta: Pustaka Pelajar.

Darajat, Zakiyah. 1978. Ilmu Jiwa Agama. Jakarta: Bulan Bintang.

Departemen Pendidikan Nasional. 2008. Kamus Besar Bahasa Indonesia. Jakarta: Balai Pustaka.

Dwi, Eni. 2012. Facebook bagi Pelajar Bermanfaat atau Merugikan? dikutip dari http://sidomi.com. diakses 3 November 2012.

Ghozali, Imam. 2009. Aplikasi Analisis Multivariate dengan Program SPSS. Semarang: Badan Penerbit Universitas Diponegoro.

Giyono. 2013. Remaja. Dikutip dari http://ewintri.wordpress.com. Diakses 3 November 2013.

Hadimunah. 2012. Pengertian Perilaku Siswa, dikutip dari http://id.shvoong.com. diakses 3 November 2012.

.2012. Penyebab Perilaku Menyimpang, dikutip darihttp://id.shvoong. com. diakses 3 November 2012

Hariyanto. 2012. Perkembangan Psikologis Remaja, http://belajarpsikologi.com/ diakses 3 November 2012.

Hidayah, Zaidatul. “Perilaku Menyimpang Norma Agama dan Penanggulangannya Pada Siswa Mts N Sukoharjo. Thesis. Yogyakarta: Pasca Sarjana UII.

Hurlock, E.B., 1992. Psikologi Perkembangan, Suatu Rentang Kehidupan (Terjemahan: Istiwidiyanti dan Soedjarwo) Edisi 5, Jakarta: Erlangga, 1992.

Ilyas, Yunahar. 2006. Kuliah Akhlaq. Yogyakarta: LPPI Universitas Muhammadiyah Yogyakarta.

Istadi, Irawati. 2005. Mendidik Anak dengan Cinta. Jakarta: Pustaka Inti.

Juditha, Christiany. 2011. Hubungan Penggunaan Status Jejaring Sosial Facebook terhadap Perilaku Siswa di Kota Makasar. Jurnal Penelitian IPTEK-KOM, Vol 13 No. 1, Juni 2011, Yogyakarta: Kompasiana. 
Juju, Duminikus \& Sulianta, Feri. 2010. Hitam Putih Facebook. Jakarta: PT. Elex Media Komputindo.

Kindarto, Asdani. 2010. Efektif Blogging dengan Aplikasi Facebook. Jakarta: PT. Media Elex Komputindo.

Kusumaningtyas, Ratih Dwi. 1994. Peran Media Sosial Online (Facebook) sebagai Saluran Self Disclosureremaja Putri di Surabaya, Skripsi, Surabaya: Fisipol UPN Veteran.

Madcom. Student Book Series: Mencari Teman lewat Facebook dan Friendster Yogyakarta: Andi Offset, 2012.

Maisyarah, Hilda. 2012. Dampak Facebook Bagi Pelajar. dikutip dari http:// hildamaisyarah.blogspot.com, diakses 15 Desember 2012

Media Pendidikan. 2012. Faktor-faktor Penyebab Timbulnya Perilaku Menyimpang pada Siswa. dikutip dari $h t t p: / / b l o g . t p . a c . i d$. diakses 3 November 2012.

Monks FJ, A.M.P. Knoers dan Siti Rahayu Haditono, Psikologi Perkembangan: Pengantar dalam Berbagai Bagiannya, Yogyakarta: Gadjah Mada University Press, 1994.

Omika, Hefri Asra. 2013. Perilaku Menyimpang. Dikutip dari http://infosos. wordpress.com. diakses 3 Januari 2013.

Pratiwi, Rindia Cincinati. 2010. Implikasi Situs Jejaring Sosial (Facebook) terhadap Prestasi Belajar Siswa Kelas 2 SMA Ma'arif NU Pandaan. Skripsi. Malang: UIN Imam Malik Ibraihim.

Sahana. 2008. Facebook Indonesia Outpaces Southeast Asian Counterparts in 2008, dikutip dari http://www.insidefacebook.com. Diakses 3 November 2013.

Santoso, Fattah. 2010. Studi Islam 3. Penyunting Sudarno Shobron. Surakarta: LPID UMS.

Sarwono, Sarlito W., 2012. Psikologi Siswa, Jakarta: Rajawali Press.

Siska. 2012. Pengaruh Situs Jejaring Sosial Facebook, dikutip dari $h t t p: / / s i s q u t e 5$. blogspot.com. diakses 3 November 2012.

Sugiyono. 2011. Metode Penelitian Kuantitatif Kualitatif dan R \& D, Bandung: Alfa Beta.

Susilo, Joko. 2012. Artikel Joko Susilo Mengenai Penelitian Facebook, dikutip dari : http://www.jokosusilo.com diakses tanggal 15 Desember 2012. 
Tjiptono, Fandy. 2001. Strategi Pemasaran Edisi Pertama. Yogyakarta: Andi Offset.

Wikipedia. 2012. Perilaku Menyimpang, dikutip dari http://id.wikipedia.org diakses 3 November 2012. 